\title{
PERANCANGAN SISTEM PAKAR UNTUK MENDETEKSI PENYAKIT PADA TANAMAN CABE DENGAN METODE CERTAINTY FACTOR
}

\author{
Helmi Kurniawan ${ }^{1}$ \\ Iwan Fitrianto Rahmad ${ }^{2}$ \\ e-mail :helmikk12@gmail.com,iwan@potensi-utama.ac.id.
}

Diterima : 20 Oktober 2011 / Disetujui : 27 Oktober 2011

\begin{abstract}
The Chilli in scientific language called Capsium annuum is not native to Indonesia, but came from the Americas, to be precise and South America Central America and Mexico. Quite a lot of chilli plants cultivated in Indonesia, especially in the land - the land of paddy fields and land - dry land that gets enough sunlight. In general, chilli plants grown as crops. Chilli and cultural communities, especially communities Medan Indonesia can hardly be separated, especially in cooking. Unlike the people - Europeans, Americans, and several Asian countries who prefer spicy pepper, Indonesian people especially people prefer spicy chili field. Virtually all the serving dishes found in cuisines that contain chilli although only slightly. Community needs for chili plants increases, along with the increasing growth of the community and increased social welfare. Although the need for chili plants increased, but not accompanied by increased production. As for the cause it can happen because of pests, plant diseases, and less extension of the government. Artificial intelligence or artificial intelligence is a part of computer science that make the machine (computer) can do the job and as good as that done by humans. Intelligent systems (intelligent system) system was built using artificial intelligence techniques. One studied in artificial intelligence is the theory of certainty by using the theory of Certainty Factor (CF). Expert System (Expert System) is a knowledge-based programs that provide quality solutions to problems-problems of experts in a specific domain. Expert systems are computer programs that mimic the thought process and expert knowledge in solving a specific problem.
\end{abstract}

Key words: chili, expert systems, PHP, My SQL, certainty factor.

1. Dosen Jurusan Teknik Informatika, STMIK Potensi Utama

Jl. K.L. Yos Sudarso Km. 6,5 No. 3 A Tj. Mulia, Medan, Telp (061) 6640525

2. Dosen Jurusan Teknik Informatika, STMIK Potensi Utama

Jl. K.L. Yos Sudarso Km. 6,5 No. 3 A Tj. Mulia, Medan, Telp (061) 6640525 


\section{ABSTRAKSI}

Tanaman cabe dalam bahasa ilmiahnya disebut Capsium annuum bukan merupakan tanaman asli Indonesia, melainkan berasal dari Benua Amerika, tepatnya Amerika Tengah dan Amerika Selatan serta Meksiko. Tanaman cabe cukup banyak dibudidayakan di Indonesia khususnya di tanah - tanah sawah dan tanah - tanah tegalan yang mendapatkan sinar matahari yang cukup. Pada umumnya tanaman cabe ditanam sebagai tanaman musiman. Cabe dan kebudayaan masyarakat Indonesia terutama masyarakat Medan hampir tidak dapat dipisahkan, terutama dalam hal masak memasak. Berbeda dengan orangorang Eropa, Amerika, dan beberapa Negara Asia yang lebih menyukai pedasnya lada, masyarakat Indonesia terutama masyarakat Medan lebih menyukai pedasnya cabe. Hampir dalam semua sajian hidangan terdapat masakan yang mengandung cabe meskipun hanya sedikit. Kebutuhan masyarakat akan tanaman cabe semakin meningkat, seiring dengan meningkatnya pertumbuhan masyarakat dan meningkatnya kesejahteraan masyarakat. Walaupun kebutuhan akan tanaman cabe meningkat, tapi tidak diiringi dengan produksi yang meningkat. Adapun yang menyebabkan hal tersebut bisa terjadi karena adanya serangan hama, penyakit tanaman, dan kurang penyuluhan dari pemerintah. Kecerdasan buatan atau artificial intelligence merupakan bagian dari ilmu komputer yang membuat agar mesin (komputer) dapat melakukan pekerjaan seperti dan sebaik yang dilakukan oleh manusia. Sistem cerdas (intelligent system) adalah sistem yang dibangun dengan menggunakan teknik-teknik artificial intelligence. Salah satu yang dipelajari pada kecerdasan buatan adalah teori kepastian dengan menggunakan teori Certainty Factor (CF). Sistem Pakar (Expert System) adalah program berbasis pengetahuan yang menyediakan solusi-solusi dengan kualitas pakar untuk problema-problema dalam suatu domain yang spesifik. Sistem Pakar merupakan program komputer yang meniru proses pemikiran dan pengetahuan pakar dalam menyelesaikan suatu masalah tertentu.

Kata kunci : cabe, sistem pakar, PHP, My SQL, certainty factor.

\section{LATAR BELAKANG}

Perkembangan komputer dewasa ini telah mengalami banyak perubahan yang sangat pesat, seiring dengan kebutuhan manusia yang semakin banyak dan kompleks. Komputer yang pada awalnya hanya digunakan oleh para akademisi dan militer, kini telah digunakan secara luas di berbagai bidang, misalnya Bisnis, Kesehatan, Pendidikan,Psikologi,Permainan dan sebagainya. Hal ini mendorong para ahli untuk semakin mengembangkan komputer agar dapat membantu kerja manusia atau bahkan melebihi kemampuan kerja manusia.Kecerdasan buatan atau artificial intelligence merupakan bagian dari ilmu komputer yang membuat agar mesin (komputer) dapat melakukan pekerjaan seperti dan sebaik yang dilakukan oleh manusia. Sistem cerdas (intelligent system) adalah sistem yang dibangun dengan menggunakan teknik-teknik 
artificial intelligence. Salah satu yang dipelajari pada kecerdasan buatan adalah teori kepastian dengan menggunakan teori Certainty Factor (CF).

Sistem Pakar (Expert System) adalah program berbasis pengetahuan yang menyediakan solusi-solusi dengan kualitas pakar untuk problema-problema dalam suatu domain yang spesifik. Sistem Pakar merupakan program komputer yang meniru proses pemikiran dan pengetahuan pakar dalam menyelesaikan suatu masalah tertentu. Salah satu implementasi yang diterapkan sistem pakar dalam bidang pertanian. Dalam dunia pertanian terdapat berbagai jenis tanaman dan salah satunya adalah tanaman cabe.

Tanaman cabe dalam bahasa ilmiahnya disebut Capsium annuum bukan merupakan tanaman asli Indonesia, melainkan berasal dari Benua Amerika, tepatnya Amerika Tengah dan Amerika Selatan serta Meksiko. Kebutuhan masyarakat akan tanaman cabe semakin meningkat, seiring dengan meningkatnya pertumbuhan masyarakat dan meningkatnya kesejahteraan masyarakat. Adapun yang menyebabkan tanaman cabe menurun produksinya terjadi karena adanya serangan hama, penyakit tanaman, dan kurang penyuluhan dari pemerintah. Oleh sebab itu sangat dibutuhkan penyuluhan dari pemerintah kepada para petani agar dapat menghasilkan tanaman cabe yang banyak. Tetapi penyuluhan tidak bisa dilakukan setiap hari, hal itu disebabkan kurangnya tenaga penyuluh. Sehingga para petani tidak dapat berkonsultasi mengenai masalah apa yang sedang terjadi pada tanaman cabe. Oleh sebab itu, para petani pada saat sekarang ini sudah harus menggunakan media internet untuk mencari solusi dari permasalahannya.Dengan melihat hal tersebut, maka penulis pun mengambil judul mengenai Sistem Pakar untuk mendeteksi penyakit pada tanaman cabe. Adapun kegunaan dari sistem pakar ini adalah untuk membantu tugas para penyuluh untuk memberikan penyuluhan kepada para petani.

\section{PERMASALAHAN}

Berdasarkan latar belakang di atas, maka masalah dalam penelitian ini dapat diidentifikasi sebagai berikut :

1. Seringnya para petani mengalami masalah penyakit pada tanaman cabe, maka para petani membutuhkan penyuluhan untuk mengatasi masalah tersebut.

2. Penulis di sini membantu memecahkan masalah yang dihadapi petani yaitu dengan mengenali penyakit cabe melalui perangkat lunak.

3. Kurangnya para penyuluh dalam memberikan penyuluhan.

Meninjau dari pokok permasalahan yang telah diuraikan pada latar belakang masalah di atas dapat diambil rumusan sebagai berikut : 
1. Bagaimana untuk mempermudah user mengetahui penyakit yang menyerang tanaman cabe dari gejal-gejala yang ada?

2. Bagaimana menciptakan sebuah perangkat lunak yang dapat digunakan untuk membantu pembelajaran dalam bidang pertanian dalam arti lain sebagai tutorial?

\section{TUJUAN}

Berdasarkan pembahasan masalah di atas, penulisan makalah ini memiliki tujuan yaitu:

1. Untuk merancang suatu perangkat lunak yang mampu untuk mengetahui masalah penyakit cabe yang menyerang tanaman cabe.

2. Sebagai tutorial bagi penyuluh yang sama baiknya seperti pakar dengan menggunakan bahasa pemrograman.

3. Untuk memberikan informasi kepada masyarakat tentang pentingnya mengatasi penyakit yang menyerang tanaman cabe.

4. Memberikan kesempatan untuk belajar memahami dan memecahkan berbagai permasalahan yang terjadi sesuai dengan disiplin ilmu masing-masing.

\section{METODOLOGI PENELITIAN}

\section{Analisis Kebutuhan}

Untuk mencapai penyelesaian masalah, kebutuhan pokok yang harus ada pada sistem yang hendak dibangun adalah:

1. Sistem pakar yang akan dibangun harus dapat digunakan semudah mungkin oleh user, sehingga user yang awam dengan komputer dapat mengerti menggunakan sistem tersebut

2. Tampilannya harus menarik, sehingga user tidak merasa bosan membaca pertanyaan dalam komputer

3. Sistem juga harus dapat memberi kesimpulan tentang penyakit apa yang menyerang tanaman cabe rawit tersebut sehingga user dapat mengetahui apa yang terjadi.

\section{Spesifikasi dan Desain}

Secara umum sistem pakar untuk mendeteksi penyakit pada tanaman cabe ini mempunyai spesifikasi sebagi berikut:

1. Template yang penulis pakai dalam sistem ini adalah template css xhtml

2. Menggunakan bahasa pemrograman untuk web yaitu $P H P$.

3. Memanfaatkan database MySQL yang akan dikoneksikan, dalam membantu proses menentukan penyakit pada tanaman cabe tersebut. 


\section{Implementasi dan Verifikasi}

Setelah jelas apa-apa saja yang menjadi spesifikasi dan desain juga sudah dirancang, maka langkah selanjutnya memulai mengatur posisi yang tepat untuk formform pada sistem, kemudian membentuk suatu logika yang diimplementasikan dengan bahasa pemrograman. Mengkoneksikan web dengan database yang telah dirancang. Untuk mengetahui apakah sistem yang dirancang sudah dapat bekerja dengan baik maka perlu dilakukan verifikasi. Dengan demikian bila ada kesalahan atau kekurangan dapat diperbaiki terlebih dahulu

\section{Validasi}

Setelah melewati tahap implementasi dan verifikasi maka tahap selanjutnya adalah validasi.Pada tahap ini dilakukan pengujian sistem secara menyeluruh, meliputi pengujian fungsional dan ketahanan sistem. Dari validasi ini dapat diketahui kesesuaian hasil perancangan dengan analisis kebutuhan yang diharapkan.

\section{TINJAUAN PUSTAKA}

\section{Sistem Pakar}

Sistem pakar merupakan salah satu bagian dari Artificial Intelegenci. Yang terdiri dari sistem pakar, pengolahan bahasa alami, pengenalan suara, robotika dan sistem sensor, computer vision, intelligent computer-aided instruction dan game playing.

Sistem pakar adalah sistem perangkat lunak komputer yang menggunakan ilmu, fakta, dan teknik berpikir dalam pengambilan keputusan untuk menyelesaikan masalah-masalah yang biasanya hanya dapat diselesaikan oleh tenaga ahli dalam bidang tertentu. Dalam penyusunannya, sistem pakar mengkombinasikan kaidahkaidah penarikan kesimpulan (inference rules) dengan basis pengetahuan tertentu yang diberikan oleh satu atau lebih pakar dalam bidang tertentu. Kombinasi dari kedua hal tersebut disimpan dalam komputer, yang selanjutnya digunakan dalam proses pengambilan keputusan untuk penyelesaian masalah tertentu.

Keahlian adalah suatu kelebihan penguasaan pengetahuan di bidang pengetahuan tertentu yang diperoleh dari pelatihan, membaca atau pengalaman. Contoh bentuk pengetahuan yang termasuk keahlian adalah :

a. Fakta-fakta pada lingkup permasalahan tertentu.

b. Teori-teori pada lingkup permasalahan tertentu.

c. Prosedur-prosedur dan aturan-aturan berkenaan dengan lingkup permasalahan tertentu. 
d. Strategi-strategi global untuk menyelesaikan masalah.

e. Meta-knowledge (pengetahuan tentang pengetahuan).

\section{Struktur Sistem Pakar}

Struktur sistem pakar ter dari: basis pengetahuan, mesin inferensi, basis data dan antarmuka pemakai.

\section{a. Basis Pengetahuan (Knowledge base)}

Basis pengetahuan merupakan inti dari suatu sistem pakar, yaitu berupa representasi pengetahuan dari pakar. Basis pengetahuan tersusun atas fakta dan kaidah. Fakta adalah informasi tentang objek, peristiwa, atau situasi. Kaidah adalah cara untuk membangkitkan suatu fakta baru dari fakta yang sudah diketahui. Menurut Gondran (1986) dalam Utami (2002), basis pengetahuan merupakan representasi dari seorang pakar, yang kemudian dapat dimasukkan kedalam bahasa pemrograman khusus untuk kecerdasan buatan (misalnya PROLOG atau PHP).

\section{b. Mesin Inferensi (Inference Engine)}

Mesin inferensi berperan sebagai otak dari sistem pakar. Mesin inferensi berfungsi untuk memandu proses penalaran terhadap suatu kondisi, berdasarkan pada basis pengetahuan yang tersedia. Di dalam mesin inferensi terjadi proses untuk memanipulasi dan mengarahkan kaidah, model, dan fakta yang disimpan dalam basis pengetahuan dalam rangka mencapai solusi atau kesimpulan. Dalam prosesnya, mesin inferensi menggunakan strategi penalaran dan strategi pengendalian.

Strategi penalaran terdiri dari strategi penalaran pasti (Exact Reasoning) dan strategi penalaran tak pasti (Inexact Reasoning). Exact reasoning akan dilakukan jika semua data yang dibutuhkan untuk menarik suatu kesimpulan tersedia, sedangkan inexact reasoning dilakukan pada keadaan sebaliknya. Strategi pengendalian berfungsi sebagai panduan arah dalam melakukan prose penalaran. Terdapat tiga tehnik pengendalian yang sering digunakan, yaitu forward chaining, backward chaining, dan gabungan dari kedua teknik pengendalian tersebut.

\section{a. Forward Chaining}

Forward chaining atau runut maju memiliki arti mempergunakan himpunan kaidah kondisi aksi. Dalam metode ini kaidah interpreter mencocokkan fakta atau statement dalam pangkalan data dengan situasi yang dinyatakan dalam anticendent atau kaidah if. Bila fakta dalam pangkalan data telah sesuai dengan kaidah if maka kaidah distimulasi. Proses ini diulang hingga didapatkan hasil. 


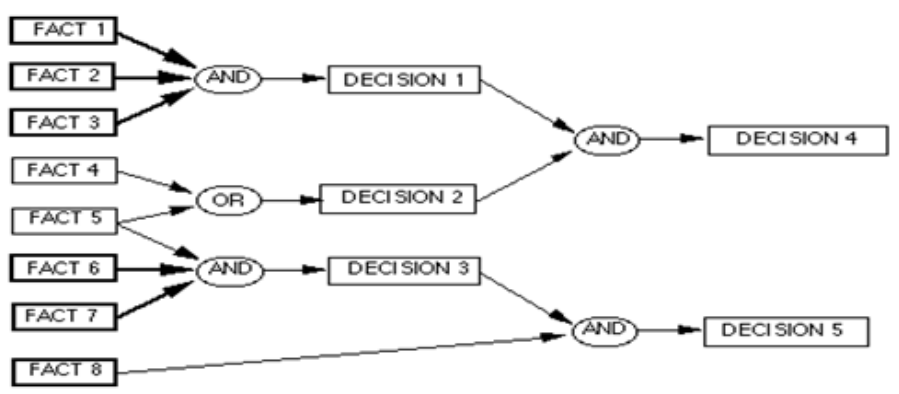

Gambar 1. Forward Chaining

Rule dasar forward chaining:

$\mathrm{A}=1, \mathrm{~B}=2$

IF $\mathrm{A}=1$ DAN $\mathrm{B}=2$ THEN $\mathrm{C}=3$

IF $\mathrm{C}=3$ THEN $\mathrm{D}=4$

$\mathrm{D}=4$

\section{b. Backward Chaining}

Suatu bentuk problem yang dimulai dengan pernyataan dan suatu himpunan aturan yang mengarah pada pernyataan dan kemudian bekerja ke belakang, menyesuaikan aturan dengan informasi dari database tentang fakta-fakta sehingga pernyataan dapat dibuktikan bernilai benar atau salah.

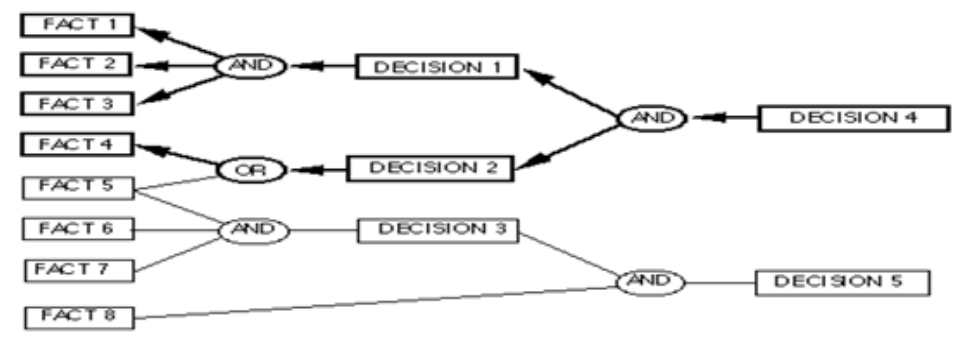

Gambar 2. Backward Chaining

\section{c. Certainty Factor}

Certainty factor(CF) yaitu merupakan nilai parameter yang diberikan untuk menunjukkan besarnya kepercayaan dan ketidakpercayaan. Dengan menunjukkan pendekatan nilai bobot dari probabilitas hasil akhir dari permasalahan. Sehingga diperoleh suatu nilai kepercayaan atau kebenaran dari aturan atau rule sebagai hasil pendekatan nilai bobot probabilitas, di mana nilai tersebut berada diantara 0 dan 1 
dengan pengertian 0 menunjukkan nilai ketidakpercayaan dari rule dan 1 menunjukkan $100 \%$ (persen) kepercayaan dari rule yang diperoleh dan terhadap suatu permasalahan.

\section{i. Basis Data (Database)}

Basis data terdiri atas semua fakta yang diperlukan, dimana fakta-fakta tersebut digunakan untuk memenuhi kondisi dari kaidah-kaidah dalam sistem. Basis data menyimpan semua fakta, baik fakta awal pada saat sistem mulai beroperasi,maupun fakta-fakta yang diperoleh pada saat proses penarikan kesimpulan sedang dilaksanakan. Basis data digunakan untuk menyimpan data hasil observasi dan data lain yang dibutuhkan selama pemrosesan.

\section{ii. Antarmuka Pemakai (User Interface)}

Fasilitas ini digunakan sebagai perantara komunikasi antara pemakai dengan sistem.

\section{Akuisisi Pengetahuan}

Akuisisi pengetahuan adalah akumulasi, transfer dan transformasi dari keahlian pemecahan masalah dari beberapa sumber pengetahuan ke program komputer untuk konstruksi atau perluasan basis pengetahuan. Sumber-sumber pengetahuan potensial termasuk pakar manusia, textbook, database, laporan penelitian khusus, dan gambargambar.

Pengakuisisian pengetahuan dari pakar adalah tugas kompleks yang sering membuat kemacetan dalam konstruksi sistem pakar sehingga dibutuhkan seorang knowledge engineer untuk berinteraksi dengan satu atau lebih pakar dalam membangun basis pengetahuan.

\section{HASIL DAN PEMBAHASAN}

\section{Analisis Masalah}

Salah satu implementasi yang diterapkan sistem pakar dalam bidang pertanian. Dalam dunia pertanian terdapat berbagai jenis tanaman dan salah satunya adalah tanaman cabe.

Kebutuhan masyarakat akan tanaman cabe semakin meningkat, seiring dengan meningkatnya pertumbuhan masyarakat dan meningkatnya kesejahteraan masyarakat. Walaupun kebutuhan akan tanaman cabe meningkat, tapi tidak diiringi dengan produksi yang meningkat. Adapun yang menyebabkan hal tersebut bisa terjadi karena adanya serangan hama, penyakit tanaman, dan kurang penyuluhan dari pemerintah. 
Oleh sebab itu sangat dibutuhkan penyuluhan dari pemerintah kepada para petani agar dapat menghasilkan tanaman cabe yang banyak. Adapun tugas dari para penyuluh tersebut adalah memberikan penyuluhan kepada para petani untuk mengatasi serangan hama dan penyakit tanaman. Tetapi penyuluhan tidak bisa dilakukan setiap hari, hal itu disebabkan kurangnya tenaga penyuluh. Sehingga para petani tidak dapat berkonsultasi mengenai masalah apa yang sedang terjadi pada tanaman cabe. Oleh sebab itu para petani pada saat sekarang ini sudah harus menggunakan media internet untuk mencari solusi dari permasalahannya.

\section{Jenis Perangkat Lunak Yang Di Pakai}

Dalam pengembangan pembuatan aplikasi sistem pakar untuk mendiagnosa penyakit cabe dengan metode Certainty Factor menggunakan fase-fase yang dibutuhkan dalam pengembangan perangkat lunak sehingga hasil akhir akan menghasilkan sistem aplikasi yang strukturnya dapat didefinisikan dengan baik. Adapun instrumen perangkat yang digunakan adalah:

1. Perangkat Lunak.

Perancangan sistem pendukung menggunakan bahasa pemograman PHP, software yang digunakan untuk penanganan database adalah MySQL dan menggunakan sistem operasi Windows XP Service Pack 2.

2. Perangkat Keras.

Kebutuhan Hardware yang digunakan untuk mendukung sistem ini dapat dilihat pada tabel dibawah ini.

Tabel 1. Kebutuhan Hardware

\begin{tabular}{|l|l|}
\hline \multicolumn{1}{|c|}{ Nama Komponen } & \multicolumn{1}{c|}{ Spesifikasi } \\
\hline Procesor & Pentium 4 1.8 Ghz atau lebih tinggi \\
\hline Memory & $512 \mathrm{Mb}$ atau lebih tinggi \\
\hline Harddisk & 40 Gb atau lebih tinggi \\
\hline Monitor & 14 "atau lebih tinggi \\
\hline Keyboard/Mouse & Standard \\
\hline
\end{tabular}

\section{Strategi Pemecahan Masalah}

Dalam merancang sistem diagnosa penyakit pada tanaman cabe ini penulis menggunakan metode forward chaining dalam menyelesaikan masalah, sistem diagnosa yang dirancang menyesuaikan gejala dari tanaman dengan kesimpulan yang dikumpulkan ke dalam database. 
Adapun langkah-langkah yang penulis lakukan untuk mendiagnosa penyakit cabe adalah sebagai berikut:

1. Mengumpulkan teori-teori penyakit tanaman cabe

Dalam tahapan ini, penulis mengumpulkan teori-teori yang berhubungan dengan penyakit tanaman cabe, perancangan web menggunakan PHP dan MySQL. Teoriteori ini penulis kumpulkan dari beberapa sumber seperti buku-buku di perpustakaan, artikel-artikel di internet serta referensi dari beberapa makalah lain yang berhubungan dengan masalah yang dihadapi.

\section{Merancang program}

Setelah teori-teori penunjang penulis rasakan cukup, langkah selanjutnya penulis melakukan perancangan terhadap program. Program yang dirancang untuk melakukan pencocokan antara gejala tanaman cabe dengan penyakit yang telah dikumpulkan di dalam database.

Langkah pertama dalam perancangan program ini adalah merancang proses kerja sistem. Proses kerja sistem penulis rancang menggunakan sebuah bagan alir (flowchart) yang menjelaskan secara rinci proses-proses yang akan dilakukan program dalam melakukan diagnosa. Langkah berikutnya adalah merancang bentuk tampilan web. Bentuk tampilan web yang penulis rancang adalah tampilan web dengan menu-menu yang yang dapat digunakan peserta untuk berinteraksi dengan sistem yang dirancang. Dalam langkah ini penulis juga merancang algoritma pemrograman dalam bahasa pemrograman yang digunakan.

\section{Mengimplementasikan rancangan program.}

Bahasa pemrograman yang penulis pilih dalam implementasi rancangan program adalah PHP dengan database MySQL. Bahasa pemrograman ini penulis pilih karena lebih sesuai untuk sistem yang berbasis web. Pada tahapan ini, penulis mengimplementasikan rancangan tampilan program serta melakukan coding sesuai dengan bahasa pemrograman yang digunakan. Tahapan implementasi program yang penulis lakukan adalah membuat tampilan web, membuat module-module yang dibutuhkan serta membuat syntax-syntax terhadap menu-menu yang ada pada web. Pengimplementasian web pertama sekali dilakukan melalui localhost. Semua fungsi tombol dan menu-menu pada web akan di-check dan dipastikan apakah sudah berjalan sesuai fungsinya untuk selanjutnya akan di posting ke dalam sebuah web hosting. 


\section{Melakukan Pengujian Program}

Pada tahapan akhir ini, penulis melakukan serangkaian pengujian terhadap program yang dihasilkan. Pengujian-pengujian ini dilakukan untuk mencari kesalahankesalahan (error) pada program dan melakukan perbaikan-perbaikan yang dibutuhkan.

\section{Perancangan Basis Data}

Basis pengetahuan yang terdapat dalam perangkat lunak terdiri dari basis aturan dan basis gejala. Di mana seluruh isi dari basis pengetahuan disimpan ke dalam baris data. Proses ini berguna agar penelusuran data, penyimpanan data, perubahan data dapat dilakukan dengan mudah. Basis Data juga berguna sebagai media penyimpanan yang digunakan untuk menyimpan data-data penunjang sebagai inputan sistem dan kemudian diolah menjadi output sistem. Untuk keperluan sistem pakar, maka dirancang sebuah basis data yang dibuat dengan menggunakan MySQL. Basis data dirancang berisi tabel-tabel dari masing-masing relasi, yang terdiri dari 5 (lima) buah table dengan field dari masing-masing table yaitu :

1. Tabel CF, terdiri dari id,id_gejala,id_penyakit, mb,md. Tabel ini berfungsi sebagai menyimpan nilai dari Certaity Factor dari setiap gejala dan penyakit.

2. TabelCF_Term, terdiri dari id,term, nilai. Tabel ini berfungsi sebagai tempat penyimpanan seberapa pastikah seorang user menderita penyakit dari gejala yang dijawab oleh $u$ ser.

3. Tabel gejala, terdiri dari id, gejala, pertanyaan, ifyes, ifno, stop, mb, md. Tabel ini berfungsi sebagaitempat penyimpanan data jenis-jenis gejala penyakit cabe dari setiap penyakit.

4. Tabel login, terdiri dari id, user, password . Tabel ini berfungsi sebagai data akses admin yang berguna untuk merubah database dari system pakar ini.

5. Tabel penyakit, terdiri dari id dan nama_penyakit. Tabel ini berfungsi sebagai tempat penyimpanan jenis-jenis dari penyakit.

\section{Analisa Sistem}

Dari analisa masalah yang telah di jelaskan diatas maka penulis akan membuat analisa sistem yang akan digunakan untuk mengetahui penyakit cabe pada penderita. Adapun sistem yang digunakan pada penyakit cabe yaitu menggunakan sistem pakar untuk mengindentifikasi atau penyebab dari penyakit pada cabe dengan menggunakan metode certainty factor. Berdasarkan identifikasi masalah telah dijelaskan di atas dapat disimpulkan bahwa prinsip kerja pada sistem pakar untuk mendeteksi penyakit pada cabe adalah sebagai berikut : 
1. Membuat basis pengetahuan yang menampung data ciri-ciri penyakit pada tanaman cabe. Data lainnya dalam bentuk suatu basis data yang digunakan dalam sistem.

2. Membangun basis pengetahuan untuk menganalisa suatu masalah tertentu dan selanjutnya akan mencari penyakit apa yang diderita oleh tanaman yang ditanam oleh user. Sistem ini dapat dikatakan sebagai sistem pengambilan keputusan.

3. Merancang antarmuka pemakai yang dapat menjangkau semua kebutuhan pemakai tanpa mempersulit atau membingungkan user dalam penggunaan sistem ini.

\section{Disain Sistem}

Pada tahap ini dilakukan disain terhadap sistem yang diusulkan secara keseluruhan. Disain sistem secara umum dapat digambarkan dengan Konteks Diagram dan Data Flow Diagram.

\section{Diagram Konteks}

Untuk memahami bagaimana sistem yang nantinya akan dibangun dapat dilihat proses sistem secara garis besar melalui Data Flow Diagram(DFD) seperti terlihat pada kontek diagram berikut ini :

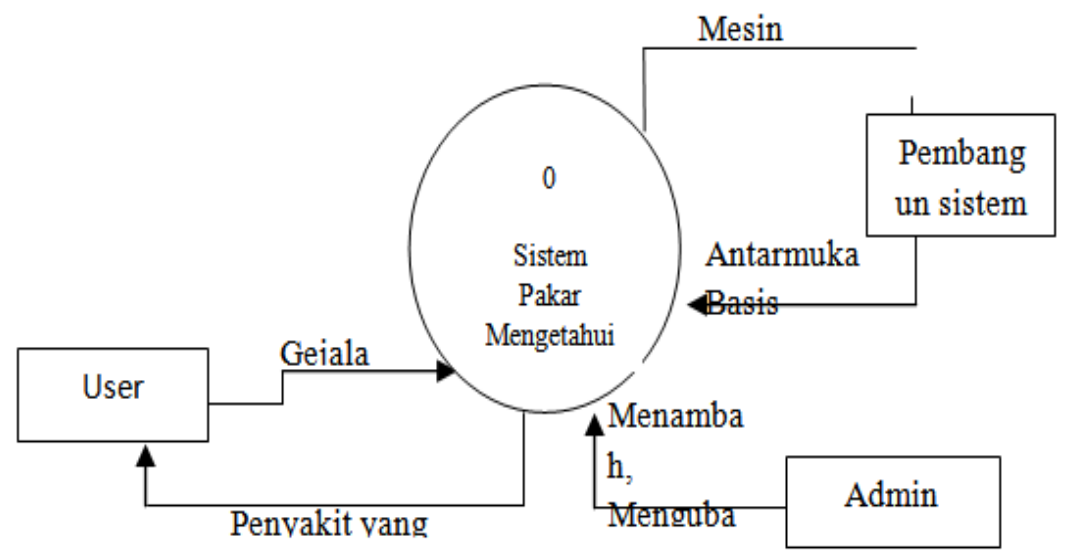

Gambar 3. Diagram Konteks Sistem Pakar Mengetahui Penyakit Pada Tanaman Cabe

Adapun keterangan dari Diagram Konteks Perancangan aplikasi sistem pakar untuk mendiagnosa penyakit pada tanaman cabe sebagai berikut : 
1. User merupakan petani yang membutuhkan informasi tentang penyakit pada tanaman cabe. User memberikan jawaban-jawaban dari gejala yang ditanyakan sistem dan hasil dari jawaban-jawaban tersebut akan menampilkan kesimpulan yaitu penyakit yang diderita oleh tanaman cabe.

2. Mesin referensi adalah proses dimana pengamatan dan pertanyaan-pertanyaan diolah menjadi sebuah solusi/pengetahuan baru.

3. Administrator berfungsi untuk mengubah data pengguna sistem pakar.

\section{DFD Level 0}

Ada pun pada DFD level 0 ini menjelaskan tentang proses - proses utama sistem serta data yang mengalir. Di sini akan diuraikan terlebih dahulu bahwa sistem pakar ini mempunyai du pengguna sistem dengan penjelasan sebagai berikut:

1. Administrator adalah orang yang mempunyai kewenangan penuh atas sistem.

2. User adalah orang yang dapat mengakses sistem dengan keterbatasan pengolahan data. Dalam mengakses sistem seorang user hanya dapat melihat data-data yang berhubungan dengan kebutuhannya tanpa dapat mengubah atau memanipulasi data.

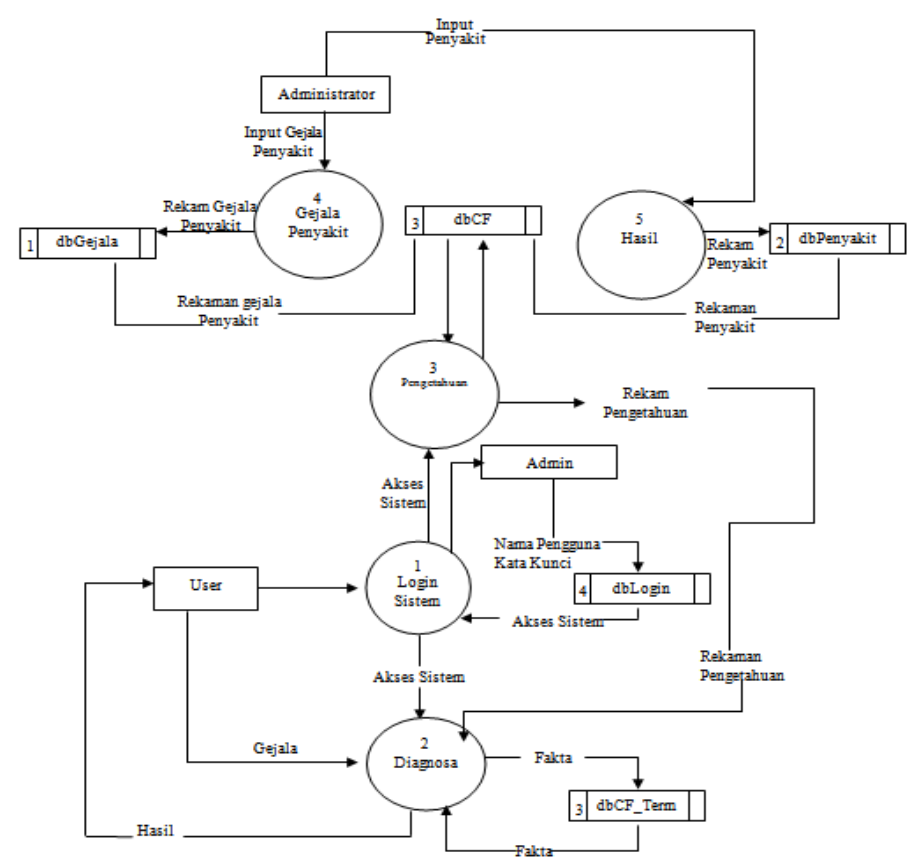

Gambar 4. DFD Level 0 Sistem Pakar Penyakit Cabe 


\section{Flowchart Sistem}

Sebelum melakukan implementasi terlebih dahulu dilakukan perancangan sistem dengan menggunakan diagram alir. Secara garis besar, diagram alir aplikasi ini terdapat pada gambar berikut :

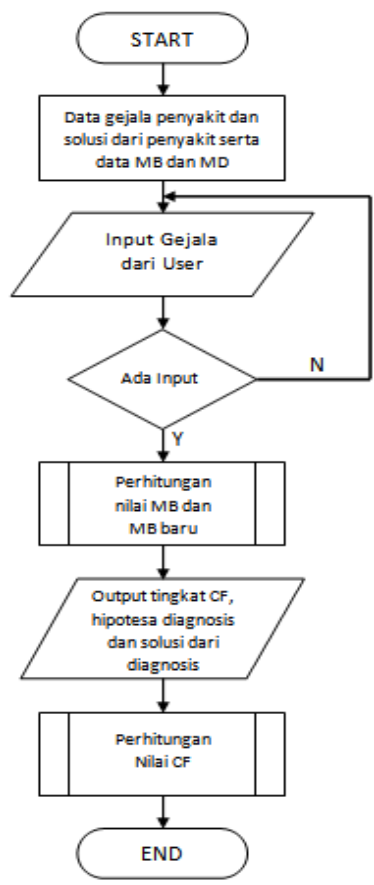

Gambar 5. Diagram Alir Diagnosa Penyakit

\section{Basis Pengetahuan}

Basis pengetahuan merupakan representasi dari hasil proses akuisisi pengetahuan dimana dalam akuisisi pengetahuan ini dilakukan pengumpulan datadata pengetahuan yang menjadi satu masalah dari pakar dan dijadikan dokumentasi untuk diolah dan diorganisasikan menjadi pengetahuan. Pengetahuan yang diperoleh harus direpresentasikan menjadi basis pengetahuan yang selanjutnya dikodekan, diorganisasikan dan digambarkan dalam bentuk rancangan lain menjadi bentuk yang nantinya dapat menunjukkan suatu kecerdasan. Pengetahuan yang diperoleh direpresentasikan ke dalam metode dan kaidah sebagai proses pemecahan masalah. Dalam memecahkan permasalahan metode yang digunakan adalah metode Certainty Factor (CF) dan kaidah produksi If-Then, proses awal yang dilakukan dalam 
pembentukan kepakaran adalah pembuatan tabel keputusan, lalu pengkonversian tabel dan hasil kesimpulan di masukkan ke dalam metode yaitu Certaity Factor untuk mendapatkan solusi dari kesimpulan yang diperoleh. Pembuatan tabel keputusan merupakan suatu cara untuk mendokumentasikan pengetahuan dimana tabel keputusan ini mendeskripsikan pengetahuan.

Pada Bagian ini diberikan contoh proses akuisisi dan representasi pengetahuan suatu perangkat dalam hal ini adalah gejala-gejala dan penyakit, seperti pada tabel 2.]

Tabel 2. Tabel Keputusan Gejala-Gejala dan Penyakit

\begin{tabular}{|c|l|c|c|c|c|c|c|c|}
\hline No & Penyakit & A & B & C & D & E & F & G \\
\hline 1 & Bercak-bercak putih bersudut & & & & & V & & \\
\hline 2 & Daun berlubang & & & & & V & & \\
\hline 3 & Daun mengeriting & & & & & & & $\sqrt{ }$ \\
\hline 4 & Pertumbuhan terhambat(kerdil) & & & & & & & V \\
\hline 5 & Daun menguning & & & & & & $\sqrt{ }$ & \\
\hline 6 & Muncul bercak coklat kehitaman pada daun, buah & $\sqrt{ }$ & & & & & & \\
\hline 7 & Buah menjadi tampak basah dan membusuk & $\sqrt{ }$ & & & & & & \\
\hline 8 & Layunya tanaman cabe yang baru berkecambah & & $\sqrt{ }$ & & & & & \\
\hline 9 & $\begin{array}{l}\text { Bercak-bercak kecil coklat yang dikelilingi wama } \\
\text { kuning pada daun }\end{array}$ & & & $\sqrt{ }$ & & & & \\
\hline 10 & $\begin{array}{l}\text { Bercak-bercak hitam pada buah dengan bagian } \\
\text { tengah berwama putih }\end{array}$ & & & $\sqrt{ }$ & & & & \\
\hline 11 & $\begin{array}{l}\text { Muncul tepung putih pada daun, ranting, bunga, } \\
\text { dan daun }\end{array}$ & & & & $\sqrt{ }$ & & & \\
\hline 12 & Daun mengulung & & & & $\sqrt{ }$ & & & \\
\hline 13 & $\begin{array}{l}\text { Munculnya bercak putih berukuran besar dengan } \\
\text { bentuk tidak teratur }\end{array}$ & & & & & & $\sqrt{ }$ & \\
\hline 14 & Tanaman gagal membentuk buah & & & & & & & $\sqrt{ }$ \\
\hline
\end{tabular}
Keterangan: A : Penyakit Busuk Buah
D : Penyakit Embun Tepung
G :Virus
B : Penyakit Layu Semai
E :Penyakit Bercak Bakteri
C : Penyakit Antraknosa
F : Penyakit Bercak Daun

\section{Mesin Inferensi}

Metode yang digunakan adalah Metode Forward Chaining (Pelacakan ke Depan), menggunakan pendekatan Data / Data Driven. Aturan dapat digunakan untuk menciptakan beberapa aturan baru. Berikut gambar Diagram pohon klasifikasi untuk pelacakan ke depan Penyakit Cabe 


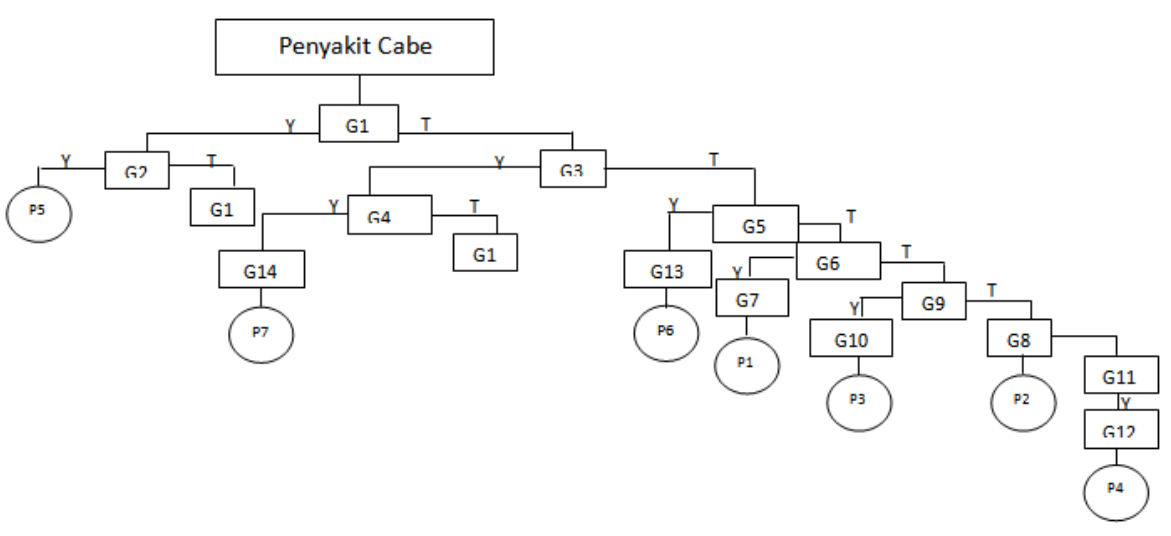

Gambar 6 Mesin Inferensi dari Penyakit Tanaman Cabe

Setelah proses akuisisi dan representasi dilakukan, maka berdasarkan tabel keputusan tersebut dicari kesimpulan dengan menggunakan metode certanty factor (CF). CF merupakan metode penggabungan dari kepercayaan dan ketidak percayaan untuk suatu permasalahan, dengan menunjukkan pendekatan nilai bobot dari probabilitas hasil akhir dari permasalahan. Sehingga diperoleh suatu nilai kepercayaan atau kebenaran dari aturan atau rule sebagai hasil pendekatan nilai bobot probabilitas, di mana nilai tersebut berada diantara 0 dan 1 dengan pengertian 0 menunjukkan nilai ketidakpercayaan dari rule dan 1 menunjukkan 100\% (persen) kepercayaan dari rule yang diperoleh dan terhadap suatu permasalahan. Pendekatan nilai bobot dari probabilitas dapat diberikan dengan nilai diantara e"0 dan d"1, sehingga sebagai contoh dapat diasumsikan bahwa faktor kepercayaan dari rule itu sendiri adalah 0.8 dan gabungan dari rule yang lain untuk diperoleh kesimpulan. Diagram pohon yang sudah dibuat pengetahuannya dari pengembangan tabel pertanyaan dan hasil/ kesimpulan dapat direpresentasikan menggunakan kaidah produksi sebagai berikut Aturan Produksi (Rule)

- Rule 1= If gejala: Bercak-bercak putih bersudut And Daun berlubang Then Tanaman terkena Penyakit Bercak Bakteri(P5)

- Rule 2= If gejala: Daun mengeriting And Pertumbuhan terhambat(kerdil) And Tanaman gagal membentuk buah Then Tanaman terkena Virus(P7)

- Rule 3= If gejala: Daun Menguning And Munculnya bercak putih berukuran besar dengan bentuk tidak teratur Then Tanaman terkena Penyakit Bercak Daun(P6) 
- Rule 4=If gejala: Muncul tepung putih pada daun, ranting, bunga, dan daun And Daun mengulung Then Tanaman terkena Penyakit Embun Tepung(P4)

- Rule 5= If gejala: Bercak-bercak kecil coklat yang dikelilingi warna kuning pada daun And Bercak-bercak hitam pada buah dengan bagian tengah berwarna putih Then Tanaman terkena Penyakit Antraknosa(P3)

- Rule 6= If gejala: Layunya tanaman cabe yang baru berkecambah Then Tanaman terkena Penyakit Layu Semai(P2)

- Rule 7= If gejala: Muncul bercak coklat kehitaman pada daun, buah And Buah menjadi tampak basah dan membusuk Then Tanaman terkena Penyakit Busuk Buah(P2)

\section{Penerapan Metode Certainty Factor}

Certainty Factor (CF) menunjukkan ukuran kepastian terhadap suatu fakta atau aturan. notasi faktor kepastian :

dengan:

$$
\mathrm{CF}[\mathrm{h}, \mathrm{e}]=\mathrm{MB}[\mathrm{h}, \mathrm{e}]-\mathrm{MD}[\mathrm{h}, \mathrm{e}]
$$

$\mathrm{CF}[\mathrm{h}, \mathrm{e}]=$ faktor kepastian

$\mathrm{MB}[\mathrm{h}, \mathrm{e}]=$ ukuran kepercayaan terhadap hipotesis $\mathrm{h}$, jika diberikan evidence $\mathrm{e}$ (antar 0 dan 1).

$\mathrm{MD}[\mathrm{h}, \mathrm{e}]=$ ukuran ketidakpercayaan terhadap evidence $\mathrm{h}, \mathrm{jik}$ diberikan evidence e (antara 0 dan 1$)$.

Aturan yang digunakan adalah faktor kepastian dari suatu aturan menjadi input untuk aturan yang lainnya maka: $\mathrm{MB}[\mathrm{h}, \mathrm{s}]=\mathrm{MB}^{\prime}[\mathrm{h}, \mathrm{s}] * \max (0, \mathrm{CF}[\mathrm{s}, \mathrm{e}])$ Dengan MB' $[\mathrm{h}, \mathrm{s}]$ adalah ukuran kepercayaan $\mathrm{h}$ berdasarkan keyakinan penuh terhadap validitas. Contoh :

Aturan 1 :If gejala: Bercak-bercak putih bersudut And Daun berlubang Then Tanaman terkena Penyakit Bercak Bakteri(P5)

Aturan 2 :If gejala: Daun mengeriting And Pertumbuhan terhambat(kerdil) And Tanaman gagal membentuk buah Then Tanaman terkena Virus(P7)

Aturan 3 :If gejala: Daun Menguning And Munculnya bercak putih berukuran besar dengan bentuk tidak teratur Then Tanaman terkena Penyakit Bercak Daun(P6)

Aturan 4 :If gejala: Muncul tepung putih pada daun, ranting, bunga, dan daun And Daun mengulung Then Tanaman terkena Penyakit Embun Tepung(P4)

Aturan 5 :If gejala: Bercak-bercak kecil coklat yang dikelilingi warna kuning pada daun And Bercak-bercak hitam pada buah dengan bagian tengah berwarna putih Then Tanaman terkena Penyakit Antraknosa(P3) 
Aturan 6 :If gejala: Layunya tanaman cabe yang baru berkecambah Then Tanaman terkena Penyakit Layu Semai(P2)

Aturan 7 :If gejala: Muncul bercak coklat kehitaman pada daun, buah And Buah menjadi tampak basah dan membusuk Then Tanaman terkena Penyakit Busuk Buah(P2)

Dari aturan - aturan diatas mengenai gejala penyakit sampai solusi yang disaran berdasarkan pengetahuan studi kepustakaan maka nilai faktor kepastiannya terhadap data - data dan fakta diatas dipastikan bernilai 0.9, dikarenakan pertanyaan pertanyaan serta solusi dari sistem tersebut dijawab dengan mengacu pada aturan yang dipakai, dan data-data yang ada.

\section{Aplikasi Sistem Pakar Penyakit Tanaman Cabe}

Pada form terdapat form informasi berisikan informasi tentang jenis-jenis tanaman cabe yang akan ditunjukkan pada gambar 7 .

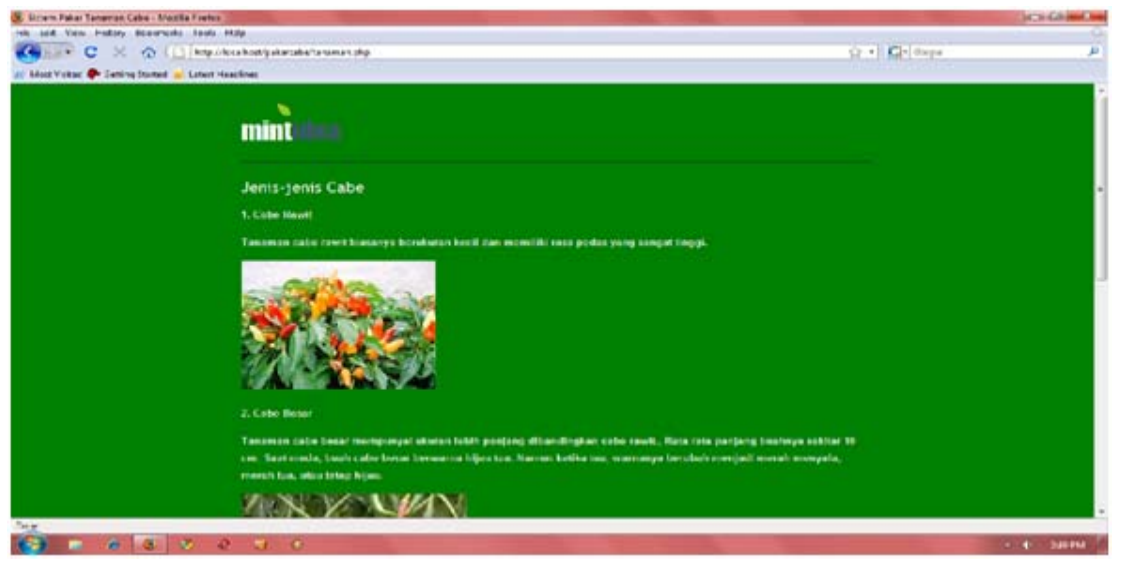

Gambar 7. Form Informasi

\section{Diagnosa Untuk Jawaban Ya}

Jika tanaman cabe milik user mengalami penyakit, maka sistem sistem ini dapat digunakan untuk melakukan diagnosa terhadap gejala yang diderita tanaman milik user. Hal ini dapat dilihat pada gambar 8 . 


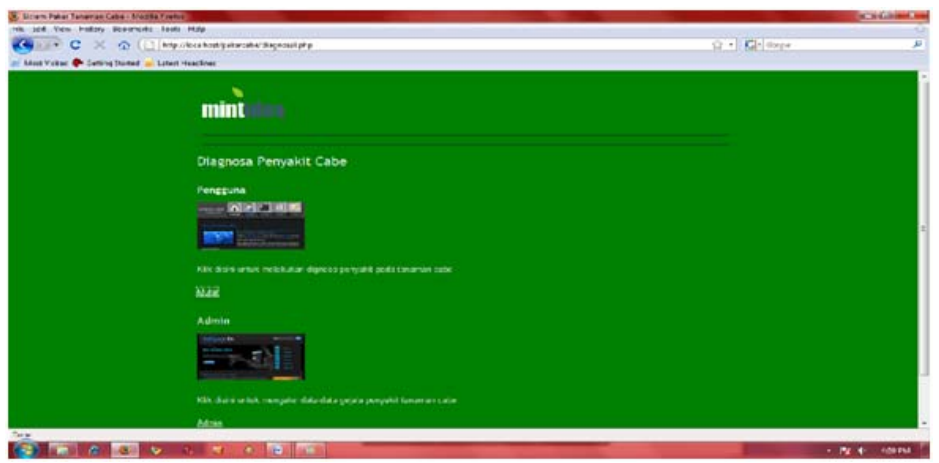

Gambar 8. User Pengguna Memilih Form Diagnosa

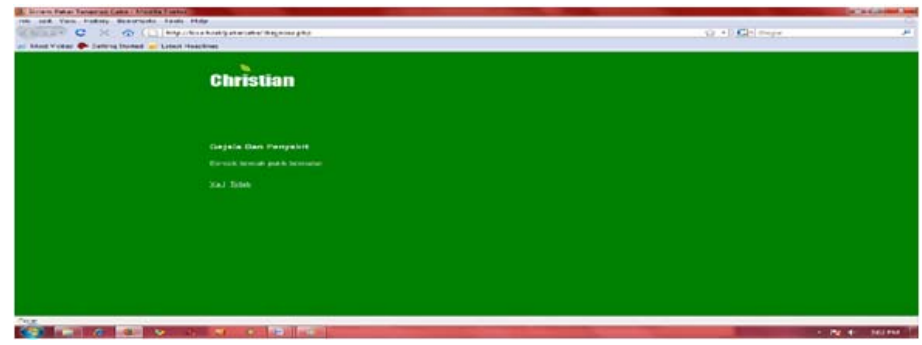

Gambar 9 Jawaban Ya dari Bercak-Bercak Putih Bersudut

Setelah user mengklik menu mulai maka akan dimulai dengan muncul gejala yang pertama yaitu bercak-bercak putih bersudut, kemudian mengklik tombol Ya atau Tidak, jika user mengklik menu Ya maka akan muncul gejala selanjutnya, seperti pada gambar 10 .

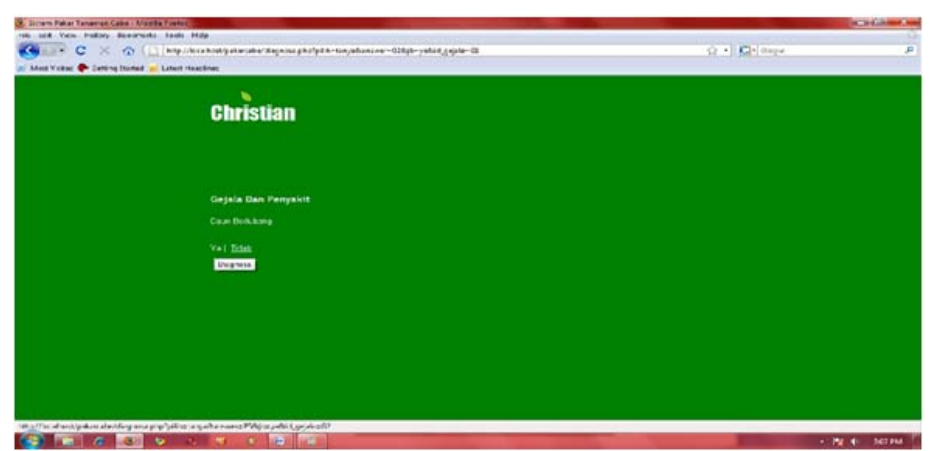

Gambar 10. Jawaban Ya dari gejala daun berlubang 
Dengan pilihan ya dari gambar sebelumnya, maka sistem akan menunjukkan hasil diagnosanya seperti ditunjukkan pada gambar 11.

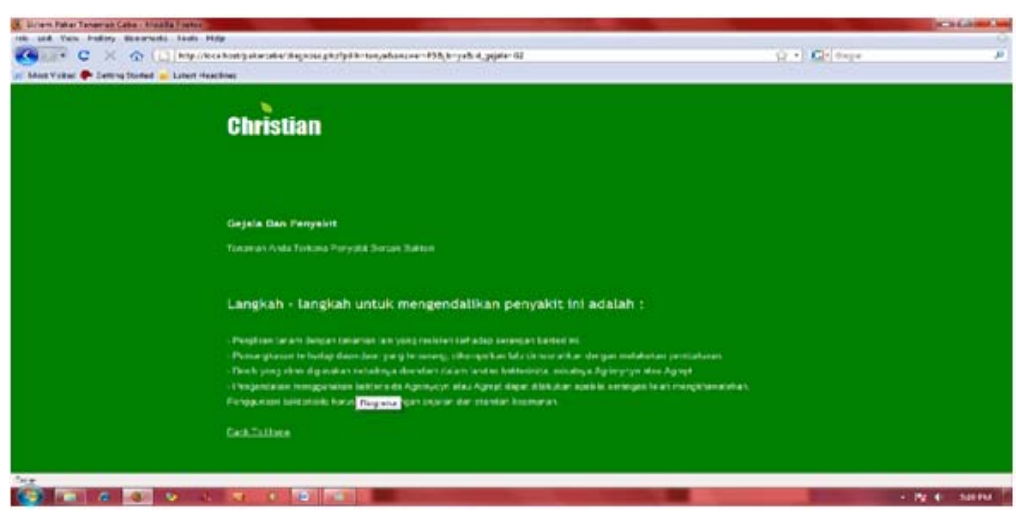

Gambar 11. Hasil diagnosa sistem pakar penyakit cabe

\section{KESIMPULAN}

Dengan adanya aplikasi sistem pakar untuk mendiagnosa penyakit pada tanaman cabe ini maka penulis dapat mengambil beberapa kesimpulan yakni :

1. Aplikasi ini menggunakan Metode Certainty Factor, di mana metode mengumpulkan pertanyaan - pertanyaan serta solusi dari sistem tersebut dijawab dengan mengacu pada aturan yang dipakai, dan data-data yang ada.

2. Aplikasi sistem pakar ini dapat digunakan untuk mempercepat pencarian dan pengaksesan pada ilmu pengetahuan oleh masyarakat atau orang - orang yang membutuhkan informasi mengenai tanaman cabe. Sehingga tidak perlu menunggu penyuluh untuk memberikan penyuluhan.

3. Pada aplikasi sistem pakar untuk mendiagnosa penyakit pada tanaman cabe bisa juga digunakan sebagai pedoman atau tutor bagi para penyuluh.

\section{PUSTAKA}

1. Basalamah,Affn, 2001, Teknologi Multimedia,PT. Elex Media Komputindo, Jakarta.

2. Kasiman Paranginangin, 2006,Aplikasi Web dengan PHPdan MySQL,Andi, Yogyakarta.

3. Kusrini, S.Kom, 2006, Sistem Pakar Teori Dan Aplikasi, Penerbit ANDI Yogyakarta. 
4. Soewito M .D .S, 1988, Memanfaatkan Lahan 2 : Bercocok Tanam Cabai, Penerbit CV Titik Terang. Jakarta.

5. Sunaryono, Hendro, 1988, Pengantar Dasar Horticultural, Penerbit Sinar Baru. Bandung.

6. Sunaryono, Hendro, 1988, Budidaya Cabai Merah, Penerbit Sinar Baru. Bandung.

7. Warisno, 2010, Peluang Usaha dan Budidaya Cabai, PT. Gramedia Pustaka Utama. Jakarta.

8. Wiwit Siswoutomo, 2004, Koneksi PHP ke Berbagai Database dengan ADOdb, PT. Elex Media Komputindo, Jakarta 